\title{
FIXED TIME PERIOD MODELLING FOR INVENTORY CONTROL SYSTEM IN REGIONAL WAREHOUSING
}

\section{PEMODELAN FIXED TIME PERIOD UNTUK SISTEM PENGENDALIAN PERSEDIAAN PADA GUDANG REGIONAL}

\author{
Taufik Djatna* dan Bagas Ari Wicaksono \\ Department of Agroindustrial Technology, Faculty of Agricultural Technology and Engineering, \\ Bogor Agricultural University, Indonesia \\ IPB Campus Dramaga Bogor, PO BOX 220 BOGOR 16001 \\ Email: taufikdjatna@apps.ipb.ac.id, bagas354wicaksono@gmail.com \\ Makalah: Diterima 20 Juli 2019; Diperbaiki 15 Februari 2020; Disetujui 1 Maret 2020
}

\begin{abstract}
ABSTRAK
Pengendalian persediaan pada perusahaan mampu mengoptimalkan biaya penggudangan dan tersedianya bahan baku dan produk, sekaligus dengan menjaga terjadinya gangguan tingkat kepuasan pelanggan. Faktanya tidak seтиа perusahaan dapat menerapkan pengendalian persediaan yang cocok seperti penggunaan metode peramalan yang kurang akurat dengan keterbatasan data. Pada pekerjaan ini formulasi pemodelan peramalan inventory menggunakan fuzzy time series untuk pendekatan fixed-time period dengan safety stock. Model ini bertujuan untuk mendapatkan kapasitas penyimpanan yang paling optimal pada setiap gudang regional. Akurasi peramalan diuji dengan mengukur tingkat kesalahannya menggunakan indikator MAPE. Hasil peramalan digunakan untuk menghitung banyaknya produk yang harus dikirim pada setiap gudang regional per periode. Perhitungan banyaknya boks produk harus diproduksi harus disesuaikan dengan level kapasitas dan jumlah produksi setiap produk. Hasil menunjukan bahwa peramalan yang didapat dari enam produk yang dikirim ke empat daerah masing-masing menghasilkan nilai ramal yang memiliki rentang nilai MAPE minimal sebesar 0,29\% dan maksimal sebesar 1,94\%. Implementasi formulasi ini dalam kasus dunia nyata mampu untuk meningkatkan aliran data antar stakeholder.
\end{abstract}

Kata kunci: formulasi, pemodelan, pengendalian persediaan, peramalan fuzzy time series, MAPE.

\section{ABSTRACT}

Inventory control modelling is utilized to optimize warehousing cost and the availability of product and raw material while keeping customer satisfaction level. A formulation of fuzzy time series based on raw material planning for fixed-time period safety stock model was proposed to enhance forecasting accuracy in limited data availability. Safety stock levels were computed in monthly fashion to optimizing the most appropriate capacity in each regional warehouse. Forecasting accuracy was based on MAPE indicator. By deploying forecasted data, the calculation of product quantity and capacity level were set to correspond with the target of product box quantity to produce. The result showed that the forecasting of six products in four regions showed the range of MAPE values with minimum at $0.29 \%$ and maximum at $1.94 \%$ level. The implementation of formula on a real field application had increased the data flow transaction and mobility amount among stakeholders.

Keywords: formulation, fuzzy tim series forecasting, inventory control, modelling, MAPE

\section{INTRODUCTION}

The traditional inventory models generally based on parameters as crisp. In practical situations, inventory control involves a range of uncertain situations such as demand and supply on one hand and control on the cost components on the other. The various elements associated with how much to order are normally concerned with inventory costs and inventory lot sizing models. The inventory cost includes the ordering cost, procurement cost, holding cost and shortage cost (Deb et al., 2018). An inventory control system is used to keep inventories in a desired state while continuing to adequately supply customers, and its success depends on maintaining clear records on a periodic or perpetual basis (Efrilianda et al., 2018; Lin, 2020; Singh et al., 2018). There are two types of inventory model based on stock period, single-period inventory model (SPIM), and multi-period inventory model (MPIM). SPIM is designed for products that are highly perishable like newspapers. In another case, MPIM is designed for the stock able product. MPIM has two general types, there are fixed-order quantity (FOQ) models and fixed-period (FTP) models. The difference between both of the systems is the time of place and order. FTP makes an order when the review period arrives, whereas FOQ makes an order when the 
inventory position drops to the order levels (Rahman et al., 2020; Singh et al., 2018)

Inventory modeling is the representing ideal process on the real-world inventory system in another form that every time developed based on new evidence and understanding, that contains an essential part of a system or phenomenon to be more understandable, definable, calculable, visualizationable, and simulate-able (Azarskov et al., 2017; Hu et al., 2018; Maiti \& Maiti, 2006; Nita et al., 2020; Singh, 2019; Singh et al., 2018) . The model usually includes essential features needed to understand a system or phenomenon. Forecasting is the determination of value in the future using data from the present and past. The company needs to measure market demand. The most accurate forecasting becomes the basis for the correct decision -making (Deb et al., 2018; Xihao, 2008)

Fuzzy time series method does not depends on the number of data and historical patterns, and needs only little of data. This method is different from Holt's double exponential smoothing method, which needs more data to increase the accuracy of forecasting (Xihao, 2008). This study focuses on the implementation of the FTP inventory model and forecasting method provided by the herbal product shipping company. This work observed an inventory process problem in a company of herb based products. The problem arose as their current limited and shortterm inventory planning must comply with fluctuating demand in the market. There are two tasks in the problem to solve, namely to forecast the target of production rate and the correspondent that dynamic target with the capacity of available warehousing. The outcome of that phenomenon in warehouse management, such as product stock out, and a lot of planned orders resulted in higher cost.

The objectives of this study are to solve this problem explained by formulating fuzzy times series forecasting and to embed this formulation for solution of fixed time inventory model. The rest of this article provides description structure as follows: In the next section provides description of required methods to obtained solution for the objectives, then the next section present the result as solution for the problem. Finally, in the next sequential section provides a discussion of related result and eventually conclusions and recommendation section concludes in the last section.

\section{METHODOLOGY}

\section{Inventory Model Framework}

In order to fulfill the objective pre-described in the introduction, this study is divided into two major activities, which comply with the research objective explained in the previous section. First activity is data collection, where is derived from repository of historical herbs company. The second activity is quantitative formulation, which uses historical data and provides example of how solution find.

\section{Fuzzy Time Series Forecasting}

The first step of the fuzzy time series forecasting method was pre-fuzzification that was determining the sub-universe of discourse by averaged based length. The determination of average based length was done by calculating the I variable (interval) and continued by calculating $\mathrm{B}$ variable (interval base). Determination of I by calculation of the average amount of lag absolute between products demand $\mathrm{Dk}+1$ and $\mathrm{Dk}(\mathrm{k}=1,2, \ldots, 12)$ and divided it by two (Xihao, 2008). In order to illustrate the above process, the formulation is as follows

Lag Absolute $\mathrm{D}_{\mathrm{ij}}=\sum_{\mathrm{k}=1}^{\mathrm{n}}\left|\mathrm{D}_{\mathrm{ij}(\mathrm{k}+1)}-\mathrm{D}_{\mathrm{ijk}}\right| \cdots \cdots \cdots \cdots \cdots$

$$
I=\frac{\text { Lag Absolute } D_{i j}}{2(n-1)}
$$

From equations 1 and 2, then obtained an interval formulation is as follows:

$$
\mathrm{I}=\frac{\sum_{k=1}^{n}\left|D_{i j(k+1)}-D_{i j k}\right|}{2(n-1)}
$$

Where:

$\mathrm{D}_{\mathrm{i}} \quad=$ Amount of product demand in $\mathrm{i}$ - location

$$
\text { (i = 1,2,3,4) }
$$

$\mathrm{D}_{\mathrm{ij}}=$ Amount of $\mathrm{j}$ - type product demand in $\mathrm{i}-$ location $(j=1,2, \ldots, 6)$

$\mathrm{D}_{\mathrm{ijk}}=$ Amount of $\mathrm{j}$ - product demand in $\mathrm{i}$ - location at $-\mathrm{k}$ period $(\mathrm{k}=1,2, \ldots, 11)$

I = Interval

$\mathrm{n} \quad=$ Number of demand data

Interval is rounded to selected basic number based on range. Table 1 is shown interval basic with each range interval.

Table 1. Basic interval (Xihao, 2008)

\begin{tabular}{cc}
\hline Range & Basic \\
\hline $0.1-1$ & 0.1 \\
$1.1-10$ & 1 \\
$11-100$ & 10 \\
$101-1000$ & 100 \\
$1001-10000$ & 1000 \\
\hline
\end{tabular}

When the result of the calculation interval is in one of range, for example if the value 7.4 is in the range of 1.1-10, then the new interval that is used by the base interval (B) is 7 . If the value 225,7 is in the range of 101-1000, then the new interval that is used by the base interval (B) is 200 . If the value 85,7 is in 
the range of 11-100, then the new interval that is used by the base interval (B) is 90 .

As B value obtained, the next step is to determine the universe of discourse. Universe of discourse is determined based on historical data and divided into several classes interval (m). Then each class transformed the linguistic value to represent a fuzzy set. Here is an overview of the universe of discourse and some of its parts (sub-universe of discourse):

$\mathrm{U}=\left\{\mathrm{u}_{1}, \mathrm{u}_{2}, \ldots, \mathrm{u}_{\mathrm{m}}\right\}$

$\mathrm{y}=\frac{1}{\mathrm{~B}}=\frac{(\mathrm{b}-\mathrm{a})}{\mathrm{B}}$

Where,

$\mathrm{m}=1,2, \ldots, \mathrm{y}$

$\mathrm{U}=$ Universe of discourse

$\mathrm{u}_{\mathrm{m}}=\mathrm{sub}$-interval $\mathrm{m}$ from universe of discourse

When $\mathrm{O}=(\mathrm{a}, \mathrm{b})$, then obtained $\mathrm{u}_{1}$ until $\mathrm{u}_{\mathrm{m}}$ by algorithm below:

$\mathrm{u}_{\mathrm{m}}=[(\mathrm{a}+(\mathrm{m}-1) \cdot \mathrm{B}),(\mathrm{a}+\mathrm{m} \cdot \mathrm{B}))$

Where,

$\mathrm{O}=$ interval from minimum data to maximum data

1 = Length of (maximum data - minimum data)

$\mathrm{B}=$ Base interval

The next step is to calculate the frequency of occurrence data from each interval were divided then sort the interval from high to low frequencies. Interval which has a frequency of occurrence of the highest data divided into four sub-intervals, where each of them equals the last interval has the highest frequency. This data-2 is divided into three subintervals which are equal in number. Then the interval that having a frequency data is the 3rd highest divided into two sub-intervals equally large and having a frequency interval data is the 4th highest allowed to correspond with the time interval and the interval that does not have the number of times data is erased from disuse later ( Maiti \& Maiti, 2006). The proposed algorithmic steps for describing the formula is as follows:

$u_{m, s}=\left\{\begin{array}{cc}\left.\left\{\left(a+(m-1) B+(s-1) \frac{B}{f}\right),\left(a+(m-1) B+s \frac{B}{f}\right)\right]\right\}, f>1 \ldots .(5) \\ u_{m} & , f=1 \\ 0 & f=0\end{array}\right.$

Where,

$\mathrm{u}_{\mathrm{m}, \mathrm{s}}=$ sub-interval $\mathrm{s}$ (based on frequency) from sub-interval $\mathrm{u}_{\mathrm{m}}$ $\mathrm{s}=1,2, \ldots, \mathrm{f}$

$\mathrm{f}=$ frequencies data demand on universe of discourse

After determining the $u_{m, s}$ (universe of discourse based on frequency), the next process was fuzzification all $u_{m, s}$. If $\mathrm{A}$ is a fuzzy set, then it is a numbers fuzzy linguistic variables determined in accordance with the state of the universe, which is the number of intervals obtained from the first step and then these fuzzy numbers are defined according to the following model ( Maiti dan Maiti, 2006)

$\left\{\begin{array}{l}1 / u_{1}+0,5 / u_{2}, \quad c=1 \\ A_{c}=\left\{0,5 / u_{k-1}+1 / u_{k}+0,5 / u_{k+1}, 2 \leq c \leq n-1\right.\end{array}\right.$

$A_{c}=\left\{\begin{array}{lr}0,5 / u_{k-1}+1 / u_{k}+0,5 / u_{k+1}, & 2 \leq c \leq n-1 \\ 0,5 / u_{n-1}+1 / u_{n}, & c=n\end{array}\right.$

Where,

$\mathrm{X} / \mathrm{u}_{\mathrm{k}}=\mathrm{x}$ is the degree of $u_{k}$ 's interval membership $A_{c}=$ fuzzy set

When $\mathrm{c}=1$, it will be obtained fuzzy set with the least number of demand. If the $\mathrm{k}$ value continues to increase, fuzzy sets will also move from smallest fuzzy set to largest.

Fuzzy logical relationship (FLR) derived from the study of (Xihao, S., 2008), the first order FLR. If demand in the period $k$ is $D_{i j k}$ which is a member of fuzzy sets $A_{c-1}$ and the demand in the period $k+1$ which is a member of fuzzy sets of $A_{c}$, then $A_{c-1}$ is the current statue and $A_{c}$ is next statue. The formula of first order fuzzy logical relationship is $\mathrm{A}_{\mathrm{c}-1} \rightarrow \mathrm{A}_{\mathrm{c}}$

Defuzzification process determine the result of the forecast $\left(\mathrm{F}_{\mathrm{ijk}}\right)$. Defuzzification process differs each demand periods, because it depends on number of data from previous period. Based on (Deb et al., 2018; Efrilianda et al., 2018), de-fuzzification process has some rules based on demand period, there are:

1. If $\mathrm{k}=1, \mathbf{F}_{\mathbf{i j} 1}$ does not have the results because it contains no next statue fuzzy set.

2. If $\mathrm{k}=2, \mathbf{F}_{\mathrm{ij} 2}$ has a middle value results $(50 \%)$ from next statue fuzzy set.

3. If $\mathrm{k}=3$, required variable $\mathrm{P}$ dan $\mathrm{Q}$ variable, then the calculation becomes:

$\mathbf{P}=\frac{1}{2} \mathbf{x}\left|\mathbf{D}_{\mathrm{i}-2}-\mathbf{D}_{\mathrm{i}-1}\right|$

$Q=\frac{1}{2} \times u_{k}$

$\mathbf{F}_{\mathrm{ij} 3}$ has a middle value results from next statue fuzzy set when $\mathrm{P}=\mathrm{Q}, \mathbf{F}_{\mathrm{ij} 3}$ have the result $75 \%$ of next statue fuzzy set when $\mathrm{P}>\mathrm{Q}, \mathbf{F}_{\mathrm{ij} 3}$ have the result $25 \%$ of next statue fuzzy set when $\mathrm{P}<\mathrm{Q}$.

4. If $\mathbf{k}=\mathbf{3}, \mathbf{4}, \ldots \mathbf{1 2}$ require $\mathrm{W}, \mathrm{X}, \mathrm{Y}, \mathrm{Z}$ variable, then the calculation becomes:

$$
\begin{aligned}
& \mathrm{W}=\left(|| D_{\mathrm{ij}(\mathrm{k}-1)}-D_{\mathrm{ij}(\mathrm{k}-2)}|-| D_{\mathrm{ij}(\mathrm{k}-2)}-D_{\mathrm{ij}(\mathrm{k}-3)}||+D_{\mathrm{ij}(\mathrm{k}-1)}\right) \times 2 \\
& X=D_{i j(k-1)}-\left(|| D_{i j(k-1)}-D_{i j(k-2)}|-| D_{i j(k-2)}-D_{i j(k-3)}|| x 2\right) \\
& Y=\left(|| D_{i-1}-D_{i-2}|-| D_{i-2}-D_{i-3}||+D_{i-1}\right) / 2 \\
& Z=D_{i-1}-\left(|| D_{i-1}-D_{i-2}|-| D_{i-2}-D_{i-3} \| x / 2\right)
\end{aligned}
$$

$\mathbf{F}_{\mathbf{i j k}}$ has a middle value results from next statue fuzzy set when $\mathrm{W} \cap \mathrm{X} \cap \mathrm{Y} \cap \mathrm{Z} \emptyset \mathrm{Ac}, \mathbf{F}_{\mathrm{ijk}}$ have the 
result $75 \%$ of next statue fuzzy set when $\mathrm{W} \cup X \in$ $\mathbf{A}_{\mathbf{C}}, \mathbf{F}_{\mathbf{i j k}}$ have the result $25 \%$ of next statue fuzzy set when $Y \cup Z \in$ Ac.

5. If $k=13$, the next statue fuzzy set is unknown, so the forecast result by calculate the middle value of the current state.

\section{Forecasting Accuracy}

The predictive power is the most important satisfied requirement factors to determine the prediction accuracy. The accuracy of the forecast based on the historical errors of forecasts. The accuracy level of forecasting is higher if the error is getting smaller. Based on (Deb et al., 2018; Manafzadeh and Tan, 2020), the commonly used methods to summarize the historical error is MAPE.

$$
\text { MAPE }=\frac{\sum_{t=1}^{n} \frac{D_{i j k}-F_{i j k}}{D_{i j k}} \times 100}{n} \ldots \ldots \ldots \ldots \ldots \ldots
$$

\section{Order Quantity with Safety Stock}

FTP is an inventory control method where orders are periodically computed, but the order quantity is different every time, and is also called Fixed Period Deficit Ordering System. Safety stock is an additional quantity of an item held in inventory in order to reduce the risk that the item will be out of stock.

$$
\begin{aligned}
& \mathrm{SS}=\mathrm{z} . \sigma_{(\mathrm{T}+\mathrm{L}) \mathrm{ij}} \ldots \ldots \ldots \ldots \ldots \ldots \ldots \ldots \ldots \ldots \ldots \ldots \\
& \sigma_{T+L}=\sqrt{\sum_{i=1}^{T+L} \sigma_{d}^{2}} \ldots \ldots \ldots \ldots \ldots \ldots \ldots \ldots \ldots \ldots \ldots \ldots
\end{aligned}
$$

Because each day is independent and assumption $\mathrm{d}$ is constant, based on Jacobs (2015), formulation 10 and 11 will be:

$$
\sigma_{(\mathrm{T}+\mathrm{L}) \mathrm{ij}}=\mathrm{Z} \cdot \sqrt{\left(\mathrm{T}+\mathrm{L}_{\mathrm{i}}\right)\left(\sigma_{\mathrm{ij}}\right)^{2}}
$$

Where,

$\mathrm{SS}=$ Safety Stock

$\mathrm{z} \quad=$ Normal distribution of service level

$$
\text { (assumption 95\% } \rightarrow \mathrm{z}=1,64 \text { ) }
$$

$\sigma_{T+L} \quad=$ Standard deviation of demand over the review and lead time

$$
\sigma_{(\mathrm{T}+\mathrm{L}) \mathrm{ij}}=\sigma_{\mathrm{T}+\mathrm{L}} \text { for } \mathrm{j} \text {-type product in - } \mathrm{i} \text { location }
$$

Order quantity is the number of pieces ordered to replenish the inventory. Inventory is computed only at the specified time for review.

$$
\mathrm{q}_{\mathrm{ij}}=\mathrm{F}_{\mathrm{ij} 13}\left(\mathrm{~T}+\mathrm{L}_{\mathrm{i}}\right)+\mathrm{SS}+(-\mathrm{OHI})
$$

From equations 11 and 12, then obtained an optimal quantity order is as follows:

$$
\mathrm{q}_{\mathrm{ij}}=\mathrm{F}_{\mathrm{ij} 13}\left(\mathrm{~T}+\mathrm{L}_{\mathrm{i}}\right)+\mathrm{z} \sqrt{\left(\mathrm{T}+\mathrm{L}_{\mathrm{i}}\right)\left(\sigma_{\mathrm{ij}}\right)^{2}}+(-\mathrm{OHI})
$$

Where,

$\mathrm{q}_{\mathrm{ij}} \quad$ = optimal quantity order $\mathrm{j}$ - product type on i location

$\mathrm{F}_{\mathrm{ijk}} \quad$ = forecasting result

$\mathrm{L}_{\mathrm{i}} \quad=$ Lead time (assumption in all WH location: 1 day)

$\mathrm{T}=$ Time review (assumption in all $\mathrm{WH}$ location: 30 day)

$\mathrm{OHI}=$ On Handed Item

Assume that review time (T) is 30 day, lead time (Li) is 1 day, service level is $95 \%$.

\section{RESULT AND DISCUSSION}

With consideration to demand data, calculation example of SKA360g (i=1) product in Bandung regional warehouse $(j=1)$ has a 13 period demand. Demand data from March 2015 until March 2016 consecutive: 1580, 1613, 1693, 1763, 1729, 1586, 1687, 1634, 1763, 1833, 1897, 1972, 1852, can be determined set the universe $U=[1580,1972]$. First process for determining universe of discourse interval divider is calculate the interval $(I)$. interval calculation based on the formula 1 and 2 are as follows:

$I=(|1580-1613|+|1613-1693|+|1693-1763|+|1763-1729|+|1729-1586|+|1586-1687|$

$$
\begin{aligned}
& +|1687-1634|+|1634-1763|+|1763-1833|+|1833-1897|+|1897-1972| \\
& +|1972-1952|) / 2(13-1) \\
& =36.33
\end{aligned}
$$

Based on Table 1, 36.33 is the member interval basic that have value 10 , so that the newly interval formed, namely base interval (B), is 40 . Length of quantity $(l)$ is $1972-1580=392$ units , so the value of universe of discourse interval divider (y) is:

$\mathrm{y}=\frac{392}{40}=9.8 \approx 10$

Divide the universe of discourse $U=[1580,1980]$ into 10 sub-interval of length equal intervals. Based on formula 4, sub-interval value follows the calculation below:

$$
\begin{aligned}
m=1,2,3, \ldots, 10 & \\
u_{1} & =[(1580+(1-1) \cdot 40),(1580+(1) \cdot 40)) \\
& =[1580,1620) \\
u_{2} \quad & =[(1580+(2-1) \cdot 40),(1580+(2) \cdot 40)) \\
& =[1620,1660) \\
u_{10} \quad & =[(1580+(10-1) \cdot 40),(1580+(10) \cdot 40)] \\
& =[1940,1980]
\end{aligned}
$$

Based on formula 3 the calculation above can be shown as bellow: 
$\mathrm{U}=\left\{u_{1}, u_{2}, u_{3}, u_{4}, u_{5}, u_{6}, u_{7}, u_{8}, u_{9}, u_{10}\right\}$ $=\{$

$[1580,1620),[1620,1660),[1660,1700),[1700,1740),[1740,1780)$,

$[1780,1820),[1820,1860),[1860,1900),[1900,1940),[1940,1980]$

After getting the universe of discourse and sub-interval, the demand data is classified to the each sub-interval. The amount of data that included in the sub-interval portion is calculated as the frequency. Table 2 shows the frequency and demand data which belong to sub-intervals.
Sub-interval of the universe of discourse which has the highest frequency is $u l$ with three frequencies so that $u_{1}$ divided into three equal intervals, namely sub of sub-interval or sub-interval based on frequencies, becomes $u_{1,1}, \quad u_{1,2}$, and $u_{1,3}$. Then the sub-interval which has two frequencies are $u_{3}, u_{5}, u_{10}$ divided into two equally intervals become $u_{3,1}, u_{3,2}, u_{5,1}, u_{5,2}, u_{10,1}$, and $u_{10,2}$. Sub-interval which has one frequency doesn't need to be divided. Then the last, sub-interval which hasn't be in frequency level is not used. Based on formula 5 , the example calculation of sub-interval based on frequency is a newly formed interval data based on frequency:

$$
\begin{aligned}
& u 1,1=\left[\left(1580+(1-1) 40+(1-1) \frac{40}{3}\right),\left(1580+(1-1) 40+(1) \frac{40}{3}\right)\right] \\
& =[1580,1593) \\
& u 1,2=\left[\left(1580+(1-1) 40+(1-2) \frac{40}{3}\right),\left(1580+(1-1) 40+(2) \frac{40}{3}\right)\right] \\
& =[1580,1593) \\
& u 10,2=\left[\left(1580+(10-1) 40+(2-1) \frac{40}{2}\right),\left(1580+(10-1) 40+(2) \frac{40}{2}\right)\right] \\
& =[1960,1980)
\end{aligned}
$$

Table 2. Frequency and demand data

\begin{tabular}{cccc}
\hline Sub UOD & $\begin{array}{c}\text { Length } \\
\text { interval (unit) }\end{array}$ & Data part of Sub-interval & Frequency \\
\hline$u_{1}$ & {$[\mathbf{1 5 8 0 , 1 6 2 0})$} & $1580,1613,1586$ & 3 \\
$u_{2}$ & {$[\mathbf{1 6 2 0 , 1 6 6 0 )}$} & 1634 & 1 \\
$u_{3}$ & {$[\mathbf{1 6 6 0 , 1 7 0 0})$} & 1687,1693 & 2 \\
$u_{4}$ & {$[\mathbf{1 7 0 0 , 1 7 4 0 )}$} & 1729 & 1 \\
$u_{5}$ & {$[\mathbf{1 7 4 0 , 1 7 8 0})$} & 1763,1763 & 2 \\
$u_{6}$ & {$[\mathbf{1 7 8 0 , 1 8 2 0})$} & - & 0 \\
$u_{7}$ & {$[\mathbf{1 8 2 0 , 1 8 6 0})$} & 1833 & 1 \\
$u_{8}$ & {$[\mathbf{1 8 6 0 , 1 9 0 0})$} & 1897 & 1 \\
$u_{9}$ & {$[\mathbf{1 9 0 0 , 1 9 4 0 )}$} & - & 0 \\
$u_{10}$ & {$[\mathbf{1 9 4 0 , 1 9 8 0}]$} & 1972,1952 & 2 \\
\hline
\end{tabular}


By using (Maiti dan Maiti, 2006) fuzzy set model, a fuzzification model was developed. For example, assume that the SKA360gr ( $\mathrm{i}=1)$ product in Bandung regional warehouse $(j=1)$ we get fuzzy set result which is followed by its interval membership degree. The fuzzification model is obtained as follows:

$$
\begin{aligned}
& \mathrm{A} 1=\mathbf{1} / \boldsymbol{u}_{1,1}+0,5 / u_{1,2}, \\
& \mathrm{~A} 2=0,5 / u_{1,1}+1 / u_{1,2}+0,5 / u_{1,3} \\
& \mathrm{~A} 13=0,5 / u_{10,1}+1 / u_{10,2}
\end{aligned}
$$

Fuzzy set is obtained from fuzzification models which have each interval. Then fuzzy set is used to compute fuzzified product demand in each period. After the fuzzification data obtained, FLR is able to determine and de-fuzzification process proceeds. By using observation data, defuzzification process for product SKA 360gr (i=1) in the regional warehouse Bandung $(j=1)$ to determine the results of forecasting $\left(\mathbf{F}_{\mathbf{i j k}}\right)$ are as follows:

1. In March $2015(\mathrm{k}=1)$, the forecasting result of $\mathbf{F}_{\mathbf{i j 1}}$ not have the results because there is no data in the previous month.

2. In April $2015(\mathrm{k}=2)$, has a degree of membership in the fuzzy set A3, at $\mathrm{u} 1,3=[1607,1620)$. Forecasting result of $\mathbf{F}_{\mathbf{i j} 2}$ is the midpoint of the interval $\mathrm{u} 1,3$ that is equal to 1613 .

3. In May $2015(\mathrm{k}=3)$, has a degree of membership in the fuzzy set A6 at $\mathrm{u} 3,2=[1680,1700)$.

Forecasting result of $\mathbf{F}_{\mathbf{i j 3}}$ based on formulation 7 are as follows:

$$
\mathbf{P}=\frac{\mathbf{1}}{\mathbf{2}} \mathbf{x}|\mathbf{1 6 1 3 - 1 5 8 0}|=16,5 \text { and } \mathbf{Q}=\frac{\mathbf{1}}{\mathbf{2}} \times \mathbf{2 0}=10
$$

Calculation show that $\mathrm{P}>\mathrm{Q}$, so the forecasting result is upward or $75 \%$ of the interval $\mathrm{u} 3,2$ that is equal to 1695 .

4. In June $2015(\mathrm{k}=4)$, has a degree of membership in the fuzzy set $A 9$, at $u 5,2=[1760,1780)$. Forecasting result of $\mathbf{F}_{\mathbf{i j 3}}$ based on formulation 8 are as follows:

$W=(|| 1693-1613|-| 1613-1580||+1693) \times 2$

$=3480$

$X=1693-(|| 1693-1613|-| 1613-1580|| x 2)$

$=1599$

$Y=(|| 1693-1613|-| 1613-1580||+1693) / 2$

$=870$

$Z=1693-(|1693-1613|-|1613-1580| / 2)$

$=1669$

Calculation show that $\mathrm{W} \cap \mathrm{X} \cap \mathrm{Y} \cap \mathrm{Z} \emptyset \mathrm{A} 9$, so the forecasting result is middle value or $50 \%$ of the interval $\mathrm{u} 5,2$ that is equal to 1770 .

5. In March $2016(\mathrm{k}=13)$ because it does not have the next state, then the results of forecasting by using the middle value of the current state that has one degree of membership in the fuzzy set A12 at $\mathrm{u} 10,1=[1940,1960)$. So the forecasting result is 1950 .

Results SKA 360gr product demand forecasting at regional warehouses are shown in Table 3

\section{Forecast Accuracy}

The predictive power is the most important factor to determine goodness of prediction results. The accuracy of the forecast based on the historical errors of forecasts. After getting the result of forecasting, the error value after forecasting is estimated based on formulation 9 .

Table 3. Forecasting result

\begin{tabular}{ccccc}
\hline Month/period & $\begin{array}{c}\text { Demand } \\
\text { (unit) }\end{array}$ & Fuzzification & FLR & $\begin{array}{c}\text { Forecasting } \\
\text { (Unit) }\end{array}$ \\
\hline Mar-15 & 1580 & A1 & - & - \\
Apr-15 & 1613 & A3 & A1-->A3 & 1613 \\
Mei-15 & 1693 & A6 & A3-->A6 & 1695 \\
Jun-15 & 1763 & A9 & A6-->A9 & 1770 \\
Jul-15 & 1729 & A7 & A9-->A7 & 1720 \\
Agu-15 & A1 & A7-->A1 & 1587 \\
Sep-15 & 1586 & A6 & A1-->A6 & 1690 \\
Okt-15 & 1687 & A4 & A6-->A4 & 1640 \\
Nov-15 & 1634 & A9 & A4-->A9 & 1770 \\
Des-15 & 1763 & A10 & A9-->A10 & 1840 \\
Jan-16 & 1833 & A11 & A10-->A11 & 1880 \\
Feb-16 & 1897 & A13 & A11-->A13 & 1970 \\
Mar-16 & 1972 & A12 & A13-->A12 & 1950 \\
Apr-16 & 1952 & - & A12-->n & 1950 \\
& - & & & \\
\hline
\end{tabular}


It is found that the range of MAPE between maximum value at $1.94 \%$, and minimum value at $0.29 \%$.

\section{Order Quantity with Safety Stock}

After being known that the results of demand forecasting using fuzzy time series have good MAPE value, then the next step is to determine the number of products shipped in each regional warehouses based on formulation 14. From the previous calculations and assumptions, it is known that the results of forecasting products $\left(\mathrm{F}_{\mathrm{ij} 13}\right)$ is 1950 unit, then $T+L_{i}=31$ and $\mathrm{z} \rightarrow 95 \%=1,65$. The 12 previous demand data, standard deviation $\left(\sigma_{i j}\right)$ of product demand is 128 . Table 4 shows the number of on handed items $(\mathrm{OHI})$ every product in each regional warehouse location.

So the results of the calculations are:

$$
\begin{aligned}
\mathrm{q}_{\mathrm{ij}} & =\mathrm{F}_{\mathrm{ij} 13}\left(\mathrm{~T}+\mathrm{L}_{\mathrm{i}}\right)+\mathrm{z} \sqrt{\left(\mathrm{T}+\mathrm{L}_{\mathrm{i}}\right)\left(\sigma_{\mathrm{ij}}\right)^{2}}+(-\mathrm{OHI}) \\
\mathrm{q}_{\mathrm{ij}} & =1950(31)+1,65 \sqrt{(31)(128)^{2}}+(-25) \\
& =2029 \text { unit }
\end{aligned}
$$

\section{Discussion}

FTP is an inventory control system where orders are periodically computed, but the order quantity is different every time, and is also called Fixed Period Deficit Ordering System. These generally require a higher level of safety stock than a fixed-order quantity system. FTP system assumes continual tracking of inventory on hand, with an order immediately placed when the reorder point is reached.
In contrast, the standard FTP models assume that inventory is counted only at the time specified for review. Safety stock is an additional quantity of an item held in inventory in order to reduce the risk that the item will be out of stock. Safety stock acts as a buffer in case the sales of an item are greater than planned and/or the supplier is unable to deliver additional units at the expected time.

Maximum value of MAPE value obtained from forecast results was $1.94 \%$, whereas the minimum value of MAPE was $0.29 \%$. As the consequent of these figures, It is in accuracy-range from the forecasting is from $98 \%$ to $99,7 \%$. The accuracy of this forecasting would remain the same regardless the pattern or amount of the data as (Amjad et al., 2018; Maiti, 2020; Xihao, 2008)) explained that Fuzzy Time Series Forecasting is not influenced by those factors. Calculation from the pre-fuzzification until the determination of the order quantity based safety stock is not only applied to the product SKA360gr in regional warehouses Bandung, but also applied to the product SKK250gr, SKK330gr, HBS KA 100, HBS KA 120, HBS KA 210 in all regional warehouses, namely Bandung, Tangerang, Cilegon, and Sukabumi areas.

\section{Advantages and Limitation}

The advantage of this research is to the ability to determine the number of order quantity to ship in each regional warehouses. Moreover, the fuzzy time series forecasting approach potentially applicable for any inventory model. The limitation of this formulation lays on its fixed time period inventory type. It requires for significant adjustment for other types of inventory model

Table 4. Number of on handed item every product in each regional warehouse

\begin{tabular}{lccccc}
\hline $\begin{array}{c}\text { Regional WH } \\
\text { Location }\end{array}$ & $\begin{array}{c}\text { Product } \\
\text { Codes }\end{array}$ & $\begin{array}{c}\text { OHI } \\
\text { (unit) }\end{array}$ & $\begin{array}{c}\text { Regional WH } \\
\text { Location }\end{array}$ & $\begin{array}{c}\text { Product } \\
\text { Codes }\end{array}$ & $\begin{array}{c}\text { OHI } \\
\text { (unit) }\end{array}$ \\
\hline Bandung & SKA360gr & 25 & Cilegon & SKA360gr & 15 \\
& SKK250gr & 34 & & SKK250gr & 43 \\
& SKK330gr & 56 & & SKK330gr & 43 \\
& HBS KA 100 & 22 & & HBS KA 100 & 15 \\
& HBS KA 120 & 330 & & HBS KA 120 & 20 \\
\hline Tangerang & HBS KA 210 & 249 & & HBS KA 210 & 5 \\
& SKA360gr & 34 & Sukabumi & SKA360gr & 18 \\
& SKK250gr & 1 & & SKK250gr & 9 \\
& SKK330gr & 14 & & SKK330gr & 14 \\
& HBS KA 100 & 154 & & HBS KA 100 & 24 \\
& HBS KA 120 & 184 & & HBS KA 120 & 77 \\
& HBS KA 210 & 73 & & HBS KA 210 & 22 \\
\hline
\end{tabular}




\section{CONCLUSION AND RECOMMENDATION}

\section{Conclusion}

This work proposed a fuzzy time series to forecasting the product demand in a herbal product distribution company. Inventory problems in each regional warehouse, where a fixed time period inventory model was applied. The accuracy is ranging from $98 \%$ to $99,7 \%$. The accuracy of this forecasting tend to remain the same regardless of the pattern or amount of the data. With respect to similar inventory model, this approach is applicable to any type of company.

\section{Recommendation}

Based on limitation previously explained, it recommends to implement the formulation with several adjustment on current data processing for a broader stakeholder inventory model.

\section{REFERENCE}

Amjad M, Shah D and Shen D. 2018. Robust synthetic control. Journal of Machine Learning Research, 19, 1-51.

Azarskov VN, Zhiteckii LS, Solovchuk KY, Sushchenko OA, Lupoi RO. 2017. Inventory control for a manufacturing system under uncertainty: Adaptive Approach. IFAC-Papers OnLine, $\quad 50 \quad$ (1): $\quad 10154-10159$. https://doi.org/10.1016/j.ifacol.2017.08.1762

Deb M, Kaur P, and Sarma KK. 2018. Inventory control using fuzzy-aided decision support system. Advances in Intelligent Systems and Computing, 554: 467-476. https://doi.org/10.1007/ 978-981-10-37733_45

Efrilianda DA, Mustafid, and Isnanto RR. 2018. Inventory control systems with safety stock and reorder point approach. 2018 International Conference on Information and Communications Technology, ICOIACT 2018, 2018-January, 844-847. https://doi.org/ 10.1109/ICOIACT.2018.8350766

Hu W, Toriello A, and Dessouky M. 2018. Integrated inventory routing and freight consolidation for perishable goods. European Journal Operational Research. 271(2): 548-560. https://doi.org/10.1016/j.ejor.2018.05.034
Lin DYF. 2020. Solution procedure for inventory models with linear and fixed backorder costs. Mathematical Problems in Engineering, 2020. https://doi.org/10.1155/2020/9316320

Maiti AK. 2020. Multi-item fuzzy inventory model for deteriorating items in multi-outlet under single management. Journal of Management Analytics.7(1): 44-68. https://doi.org/10.1080 /23270012.2019.1699873

Maiti MK and Maiti M. 2006. Fuzzy inventory model with two warehouses under possibility constraints. Fuzzy Sets and Systems. 157(1): 52-73. https://doi.org/10.1016/j.fss.2005.06.021

Manafzadeh DN and Tan B. 2020. Optimal control of production-inventory systems with correlated demand inter-arrival and processing times. International Journal Production Economics, 228. https://doi.org/10.1016 j.ijpe.2020.107692

Nita HS and Mandeep M. 2020. Optimization and Inventory Management. https://doi.org/ 10.1007/978-981-13-9698-4

Rahman MS, Duary A, Shaikh AA, Bhunia AK. 2020. An application of parametric approach for interval differential equation in inventory model for deteriorating items with sellingprice-dependent demand. Neural Computing and Applications, 0123456789. https://doi.org/ 10.1007/s00521-020-04806-w

Singh D. 2019. Production inventory model of deteriorating items with holding cost, stock, and selling price with backlog. International Journal Mathematics in Operational Research, 14(2): 290-305. https://doi.org/ 10.1504/IJMOR.2019.097760

Singh T, Mishra PJ, and Pattanayak H. 2018. An EOQ inventory model for deteriorating items with time-dependent deterioration rate, ramp-type demand rate and shortages. International Journal Mathematics in Operational Research, 12(4): $\quad$ 423-437. https://doi.org/10.1504/IJMOR.2018.092103

Xihao SLY. 2008. Average-based fuzzy time series models for forecasting Shanghai compound. World Journal Modelling and Simulation, 4(2): 104-111. 